\title{
"Visionary Gleams" : The Metaphysical Colloquy of Derek Mahon and Seamus Heaney
}

\section{Bruce Stewart}

\section{Q OpenEdition \\ 1 Journals}

\section{Electronic version}

URL: http://journals.openedition.org/etudesirlandaises/3368

DOI: 10.4000/etudesirlandaises.3368

ISSN: 2259-8863

\section{Publisher}

Presses universitaires de Rennes

\section{Printed version}

Date of publication: 30 July 2013

ISBN: 978-2-7535-2673-0

ISSN: 0183-973X

\section{Electronic reference}

Bruce Stewart, " "Visionary Gleams" : The Metaphysical Colloquy of Derek Mahon and Seamus

Heaney ", Études irlandaises [Online], 38-1 | 2013, Online since 30 June 2015, connection on 01 May 2019. URL : http://journals.openedition.org/etudesirlandaises/3368 ; DOI : 10.4000/

etudesirlandaises.3368 


\title{
"Visionary Gleams": The Metaphysical Colloquy of Derek Mahon and Seamus Heaney
}

\author{
Bruce STEWART \\ University of Ulster
}

Abstract

In April 2009 Derek Mahon contributed a poem called "A Country Kitchen" to "Seamus Heaney at 70", a supplement of the Irish Times. That poem revealed signs of a literary colloquy on poetry and metaphysics which can be traced back over the full extent of their closely concurrent careers. Mahon initially showed himself a critic of the essentialist version of Irishness which Heaney promoted through his celebrated coinage "sense of place", while Heaney appears to have adjusted his metaphysics to embrace the characteristically "placeless" anomie of Mahon's early existentialist stance in later collections, but most notably in Seeing Things (1991) which was dedicated to Mahon. The title poem of that collection raises the question : "Where does the spirit live?" The central point of this paper is, where do the greatest contemporary Irish poets stand on the questions of spirituality and immanence in a postCatholic, post-Christian and post-metaphysical world. In other terms, does the epithet "secular mysticism" associated with Mahon embrace both their outlooks and is the anti-metaphysical metaphysics implied in it a credible and a sufficient answer?

Keywords: Derek Mahon, Seamus Heaney, James Joyce, W. B. Yeats, Wordsworth, Ted Hughes, poetry and metaphysics, poetry and spirituality, poetry and transcendence, claritas, quidditas, epiphany, Seeing Things, The Autumn Wind, "sense of place", "visionary gleam".

\section{Résumé}

En avril 2009 Derek Mahon publia un poème intitulé "A Country Kitchen " dans le supplément du quotidien The Irish Times célébrant le soixante-dixième anniversaire de Seamus Heaney. Le poème pouvait se lire comme la suite d'un échange poétique entre les deux hommes sur la poésie et la métaphysique, échange dont on retrouve la trace tout au long de leurs carrières parallèles. Mahon commença par se montrer critique de la vision essentialiste de Heaney de lidentité irlandaise, devenue célèbre entre autres grâce au fameux "sens du lieu ", tandis que Heaney semble avoir évolué au cours de sa carrière dans sa vision métaphysique pour inclure la fameuse anomie du lieu, propre à la position existentialiste des débuts de Mahon, et ceci nulle part de manière plus frappante que dans Seeing Things, dédié à Mahon. Dans le poème qui donne son nom au recueil, Heaney pose la question : "Où vit l'esprit?" Cet article interroge la position de deux des plus grands poètes irlandais contemporains sur les questions de spiritualité et d'immanence dans un monde post-catholique, post-chrétien et post-métaphysique. En d'autres termes, l'épithète "mysticisme séculier" associé à Mahon inclut-il la vison des deux poètes, et la métaphysique anti-métaphysique qu'elle implique est-elle une réponse crédible et suffisante?

Mots clés: Derek Mahon, Seamus Heaney, James Joyce, W.B. Yeats, Wordsworth, Ted Hughes, poésie et métaphysique, poésie et spiritualité, poésie et transcendance, claritas, quidditas, épiphanie, Seeing Things, The Autumn Wind, "sens du lieu ", "lueur visionnaire " 
"We are still running on an unconscious that is informed by religious values, but I think my youngsters' youngsters won't have that." (Seamus Heaney, quoted in "They Said This Week", The Irish Times, 2 Nov. 2002.)

In April 2009 Derek Mahon contributed a poem called "A Country Kitchen" to an The Irish Times supplement compiled to mark Seamus Heaney's 70th birthday $^{1}$. The poem was shortly afterwards included in The Autumn Wind (2010), where it figures as the second in a triptych honouring by turn John Montague, Heaney and Michael Longley under the collective title "Autumn Skies". While the very title of the poem narrowly escapes the suspicion of parody, the whole is surely intended to honour things honoured by the poet whom it purports to honour. It does so by a curious feat of technical and imaginative emulation which tussles for ownership of the same intellectual themes, and thereby acknowledges the recipient's standing as primus inter pares rather than a thinking poet entirely sui generis. The genus to which both belong, on this showing, is a class of antimetaphysical metaphysicians who combine all the trappings of agnosticism with all the yearnings of religion - a type known to literature since Walter Pater and raised to a position of artistic exaltation by Yeats, Joyce and, arguably, Samuel Beckett among the great Irish writers.

Aside from its synchronic character as an adroit and perceptive specimen of poetic homage, Mahon's dedicatory poem seems to mark a specific moment, or even chapter, in a poetic colloquy that has been going on in prose and verse through much of a literary generation. In addition to that, it bears the aspect of a positive rapprochement, speaking of things finally agreed in the realm of theology and its modern counterpart - a state of mind which Mahon has elsewhere called "secular mysticism" ${ }^{3 "}$. There are good reasons for arguing that the project of replacing the spirituality lost in organised religion with an equally nuanced essentially non-dogmatic sense of the numinous in human affairs - or simply the "halo round a frying pan", to quote a phrase in Nabokov's The Real Life of Sebastian Knight which took Mahon's fancy too - has been a parallel adventure for Heaney and Mahon, however diverse their methods of approach to the numinous in an

1. "Heaney at 70", [Special Supplement, ed. Gerry Smyth], The Irish Times (11 April 2009), 12 p. The poem appeared on the back page and shared the same generous font as four by Heaney printed across the centre-fold of the supplement ("The Wood Road", "Chanson d'Aventure", "Miracle" and "The door was open and the house was dark" [in memory of David Hammond], p. 6-7 - all subsequently collected in Heaney's Human Chain, Oldcastle, Gallery Press, 2010.

2. The Autumn Wind (Oldcastle, Gallery Press 2010), p. 39-42. The individual poems are entitled "A Distant Echo", p. 39-40, "A Country Kitchen", p. 40-41 and "A Quiet Cottage", p. 41-42.

3. In his edition of Selected Poems of Philippe Jaccottet (Penguin 1988), Mahon wrote: "he is a secular mystic, an explorer of le vrai lieu ("the real place")" - a remark which Terence Brown quotes in his own Introduction to Mahon's critical prose as Journalism (1996), adding that Mahon's "secular mysticism finds expression" in poems such as such as "Light Music" sequence and "A Garage in Co. Cork". (See Journalism, Oldcastle, Gallery Press 1996, Introduction, p. 19). 
agnostic age. Mahon's birthday poem to Heaney is therefore susceptible to both synchronic and diachronic readings - but, I think, entirely illuminating of the common ground between the writers concerned. In this paper I'd like to offer some sense of its background in those earlier exchanges, and to suggest the interpretation we ought to place upon it.

"A Country Kitchen" is laced with allusions not only to Heaney's progress as man and poet but to Mahon's development also, as well as to James Joyce's alter ego Stephen Dedalus - who shares a purview on Dublin Bay with both of these, in spite of their common origins in another province and their biographical differences from each other in terms of "community" in the Northern-Irish sense of denominational allegiance. The opening line of Mahon's poem, rendered in quotation marks, is clearly taken from Stephen's encounter with the "reality of experience" during a morning trek across Sandymount strand in the Proteus episode of Ulysses: "Walking into eternity'/along the breathing strand $\mathrm{d}^{4} .$. " Likewise the ensuing lines in the first stanza since "seaspawn and seawrack" are hallmarked Joycean words, being "signatures of all things I am here to read" in Stephen's parlance 5 , while "modality of the visible" (prefaced in Ulysses by the word "ineluctible") is, of course, the opening phrase of the chapter in which Stephen testdrives Aristotle's epistemology as he walks "into eternity across Sandymount Strand". Mahon deftly avoids mention of the precise location by substituting "the breathing strand" for its place-name, but this hiatus is compensated by a reference to the mass of Howth Head which, as no Mahon reader needs to be reminded, evokes the title of an early collection of his $\mathrm{own}^{7}$. It is very much part of the poem's homage that it observes an exact "sense of place" - if not of name in revealing a landscape which in no way varies from the one that is ineluctibly visible through the front window of the Heaneys' home on Strand Road, Dublin. That Heaney himself has set a poem, meditating on the death of his father, on that shore adds poignancy to Mahon's gesture. Heaney's poem is likewise tied in to Joyce's Ulysses:

4. The Autumn Wind (2010), p. 40. It is probably unnecessary to annotate the reference to Ulysses nor to remind the reader of Samuel Beckett's memorable variation upon it in his essay on Joyce - viz., "Mr. Joyce's Terrestial Paradise is the tradesmen's entrance on to the sea-shore" ("Dante... Bruno. Vico. Joyce", in Our Exagmination [... \&c.], 1929; New Directions [rep.] 1972 p. 32.

5. James Joyce, Ulysses, London, Bodley Head, 1960, p. 45.

6. Viz, "Am I walking into eternity along Sandymount Strand?" (Idem.) Samuel Beckett also harped upon the sentence in his essay in Our Exagmination (1929). The point of the original is that Sandymount Strand is a commonplace location, as yet unglorified by literary tradition - that is, by Joyce's use of it in Ulysses.

7. Beyond Howth Head [Poetry Ireland Edns., II], Dublin, Dolmen, 1970, 16p. The poem, which consists of 23 stanzas and with notes, is dedicated to Jeremy Lewis. 
The dotted line my father's ashplant made

On Sandymount Strand

Is something else the tide won't wash away ${ }^{8}$.

It is just to suppose that, in writing this, he knew that Leopold Bloom employs the self-same turn of phrase when he considers the fate of his own inscription in the sands of Sandymount later in the novel: "Some flatfoot tramp on it in the morning. Useless. Washed away'." On any count, the affirmation of Heaney's elegiac poem can only be called heroically counterfactual since markings of that kind are certainly no more permanent than les neiges d'antan. In "Saw Music", the elegy to his friend Czeslaw Milosz - whose funeral Heaney attended in August 1994 - Heaney wrote: "Coffined in Krakow, as out of this world now/ As the untranscendent music of the saw/He might have heard in Vilnius or Warsaw ${ }^{10}$." That play upon transcendent in connection with the music of a busker once seen playing his strange instrument in a Belfast street epitomises the metaphysical dilemma represented by the supercession of life and the necessary illusion of translunar existence - of which more later in a Yeatsian connection.

The enchainment of details drawn from the lives of Seamus Heaney and Derek Mahon in the anniversary poem has the effect of drawing the two poets into a moving, if slightly forced, fraternal union. There are actually two kitchens and two hearths behind the references in the title and the second stanza where we are given a notion of "how" (and where) it "begins" - it being an anaphoric pronoun for which the only possible referent is poetry as a way of life: one in Bellaghy and the other in Glengormley (or, more likely, Bangor). Further allusions to one life or the other, including "plough", "gulls" and even "oracle", can be plotted easily enough in the early life of Heaney and the later poetry of Mahon. As to the implied resemblance in their formative experience, it is plausible enough to suppose that Heaney "toy[ed] with rhythm and rhyme" at the "freshly lit hearth" - though something of Francis Ledwidge seems to have crept into the picture ${ }^{11}$ but the more attestable fact is that Mahon once figured himself as "A strange child with a taste for verse", "lying low in a room", apparently beneath "a deal table", while his "hard-nosed companions dream of fire/And sword ${ }^{12}$."

There are, in addition to these passing references, at least three structural allusions to separate poems by Heaney in different periods. First to mention is

8. "The Strand", in The Spirit Level, London, Faber \& Faber, 1996, p. 62; Opened Ground (1998), p. 436.

9. Ulysses (1960), p. 498.

10. "Out of This World"/ [III:] "Saw Music", in District and Central, London, Faber \& Faber, 2006, p. 50. The series is dedicated to Hughie O'Donoghue, Ted Hughes and Milosz, while the painter Barrie Cooke is another presence in "Saw Music". The collection is dedicated to Ann Saddlemeyer.

11. Heaney contributed a foreword to a selection of Ledwidge's poems edited by Dermot Bolger. (Selected Poems, Dublin, New Island Books 1993).

12. "Courtyards in Delff", in Hunt by Night (1982); see Collected Poems, Oldcastle, Gallery Press, 1999, p. 105-106. 
the meterological scenario packed into the phrases: "from under a close blanket/ of ground fog the earth/opens up to a cloudstream/westwards in the Atlantic" (Stanza 3). I do not think it is stretching a point to see in these lines a recurrence to the landscape of Heaney's poem "Bogland", which promulgated an essentialist conception of the actual land of Ireland as an inexhaustible reservoir of identity by means of a topological metaphor - incidentally, devoid of geological truth but informed by some interesting antiquarian misprisions: "The bogholes might be Atlantic seepage/The wet centre is bottomless ${ }^{13}$."

With this thesis in any form Mahon keenly disagreed, expressing his dissent first in a poem called "The Last of the Fire Kings" in which he stated the wish to be "like the man/Who drops at night/From a moving train// And strikes out over the fields/Not knowing a word of the language ${ }^{14}$ ". Read in an Irish cultural context, this is a clear rebuke to the Irish-language school of identitarian politics. Mahon followed up with the poem "Lives", apparently the monologue of an ancient Irish "torc" that morphs into a Navaho rug before finally becoming a modern anthropologist - just the type whose mind-set is most likely to be proof against the "spirit of the nation" or any revamped version of nationalist metaphysics. It is the anthropologist who has the last word in the poem: "if [...] someone/ Thinks he has once been me [...] Let him revise/His insolent ontology/Or teach himself to pray ${ }^{15 "}$.

In the same year Mahon edited The Sphere Book of Irish Verse (1972), registering in his introduction an objection to "a poetry which evade[s] the metaphysical unease in which all poetry of lasting value has its source ${ }^{16 "}$. It is not surprising that, for contemporary critics, the poem "Lives" seemed like a riposte to "the religious intensity with which Heaney presses his self-identifications", as Elmer Andrews suggested ${ }^{17}$.

Yet much revising of ontologies was to go on, on both sides of the colloquy, in the decades ahead; and I would like to suggest that when Heaney dedicated his 1991 collection Seeing Things to Mahon, he meant to signal that he had indeed conducted an adjustment very like the one that Mahon had proposed, no less than to acknowledge that Mahon had allowed a sense of place to inform his own mature poetic in ways that seemed unlikely at that earlier moment.

13. Door into the Dark, London, Faber \& Faber, 1969 - the final poem in the collection and herald of the "Bogland" poems in next (North); rep. in New Selected Poems 1966-1987, London, Faber \& Faber, 1990, p. 17.

14. Poems, 1962-1978, Oxford, OUP 1979, p. 58; Collected Poems (1999), p. 53.

15. Lives, London, Faber \& Faber, 1972; rep. in Selected Poems 1962-1978, OUP 1979, p. 44-49, and in Collected Poems, Gallery Press, 1999, p. 52-57.

16. Sphere Book of Irish Poetry, London, Sphere Books, 1972, p. 12; cited in John Byrne, "Derek Mahon: A Commitment to Change", in Crane Bag Vol. 6, No. 1 (1982), p. 62-72, p. 62.

17. Elmer Andrews, "The Poetry of Derek Mahon: places where a thought might grown", in Andrews (ed.), Contemporary Irish Poetry: Collection of Critical Essays, London, Macmillan, 1992, p. 235-63, p. 245. 
Heaney's so-called "Bogland Poems" have been picked over so often, especially from the standpoint of cultural politics, that I propose to leave them well alone. Likewise "The Sense of Place" - a hugely influential lecture which he delivered at the Ulster Museum in January 1977. On that occasion Heaney glanced at the Protestant writers of Ulster who stood outside of the Irish tradition which he was then embracing, and identified "visionary desolation" as the characteristic mark of Mahon's work ${ }^{18}$. The critical idea behind the lecture combined a title-phrase employed in John Barrell's very English study of John Clare and "the idea of landscape ${ }^{19}$ ", with nationalist promptings from John Montague's obiter dicta and lyric examples from Patrick Kavanagh, (both extensively quoted), and finally the sanction of a Middle-Irish Gaelic lore of place-names called dinnseanchas which enabled him to say that the traditional Irish landscape was "sacramental, instinct with signs, implying a system of reality beyond the visible realities ${ }^{20 "}$ - and to argue that it should be so regarded again. "The Sense of Place" immediately became canonical; it would serve as a linch-pin in the dominant ideology of Irish criticism, and the literary credo of numerous writers, anthologists, and festival organisers for decades to come. (It stands directly behind Brian Friel's phenomenally successful play Translations, for example.) Thus Heaney's quietly ardent lecture was a turning-point; yet today it seems vieux jeu, not only because the "place" of contemporary Irish writing is more globally diffuse than then - centrifugal not centripetal - but because Heaney himself moved his artistic bivouac to a "placeless" zone in the imagination when he revised his reading of Patrick Kavanagh in a crucial lecture given in Carrickmacross in November 1985'. If Heaney saw the "whatness" or quidditas of Ireland (to borrow a Joycean term) as a subterranean affair, by 1985 he had shifted his ground from the "poetics of excavation to that of light, from earth to air" in what Jack Foster has called a "Copernican revolution ${ }^{22}$ ". In so doing, if can be argued, he approached closer to the "place" which Derek Mahon had always treated as the proper ground: "the place that the poetry occupies is not a geographical location; it's a community of imagined readership ${ }^{23}$ ", - as he told Willie Kelly in an interview of 1981.

18. Ibid., p. 148.

19. John Barrell, The Idea of Landscape and the Sense of Place 1730-1840: An Approach to the Poetry of John Clare, Cambridge UP, 1972.

20. "The Sense of Place" [1977], in Preoccupations, London, Faber \& Faber, 1980, p. 131-49; p. 132.

21. "The Placeless Heaven: Another Look at Patrick Kavanagh", in The Government of the Tongue, London, Faber, 1986, p. 3-14. I have written of this in "The Door and What Came Through It": Aspects of Influence", in Patrick Kavanagh, Dublin, ed. Stan Smith, IAP, 2009, p. 163-187.

22. J. F. Foster, "Heaney's Redress", Colonial Consequences: Essays in Irish Literature and Culture (Dublin, Lilliput 1991), p. 188.

23. Willie Kelly, "Each Poem for me is a New Beginning" [interview with Derek Mahon], Cork Review, 2 (1981), p. $10-12$, p. 11. 
The second poem by Heaney which is pointedly referenced in Mahon's birthday homage is "Sunlight", included in his 1975 North collection. The poem is set in a country kitchen, where his aunt Mary Heaney is making scones by the traditional methods of fire and griddle (or so I read the mechanics of the process). Notable details amid the heat, light and paraphernalia of the cottage interior are the "whitened nails" and "measling shins" of the cook, captured in the double perspective of past and present, absence and remembrance. The poem comes to a conclusion in a stanza which is marked by one of a salient appearance of the metaphysically-accented noun gleam (of eminent literary provenance in a fine poem of William Wordsworth)

And here is love

like a tinsmith's scoop

sunk past its gleam

in the meal-bin ${ }^{24}$.

Here, in fact, the poem ventures deep into the realm of Christian metaphysics, leading beyond the present scene towards the invisibilia about which St. Paul had something to say in his epistle to the Corinthians. The meal-scoop is made of an alloy that does retain its pristine gleam if protected from the atmosphere. At the same time it speaks of something untarnished and ultimately more real precisely because it is unseen. This, then, is the kitchen in which Heaney's poetical vision was naturally formed - and formed in a world of "simple fact" which, as Mahon's tributary poem tells us, gleams with water

$$
\text { yields }
$$

to the plough. A gull-race

follows the working tractor.

These are all credibly Heaneyesque details corresponding to poems in early collections. It is not a landscape that many would associate with Mahon himself, whose early poem "Glengormley" speaks of "man/Who has tamed the terrier, trimmed the hedge,/And grasped the principle of the watering can" - all in a suburban world where the only sensitive beings are " $[t]$ he unreconciled, in their metaphysical pain" who "[d]angle from the lamp-posts in the dawn rain" - a landscape part made from Eliot's Wasteland and part Beckett's Trilogy. (It is noteworthy that Heaney took the phrase " $t \mathrm{t}] \mathrm{he}$ unreconciled in their metaphysical pain" as the text for his remarks on Mahon in his Harvard lecture on "Place and Displacement" of $1984^{25}$.) Yet an older Mahon, grazed by nosalgia in The

24. North, London, Faber \& Faber, 1975, p. 8-9; rep. in Opened Ground: Poems 1966-1996, London, Faber \& Faber, 1998, p. 93-94.

25. "Place and Displacement: Recent Poetry from Northern Ireland" [pamph. 1985], rep. in Elmer Andrews (ed.), Contemporary Irish Poetry: A Collection of Critical Essays, London, Macmillan, 1996, p. 124-144, p. 135. 
Hudson Letter (1995), asks to be taken back "where we set out long ago, [...] the house, the stove in kitchen, the warm bed,/ the hearth, vrai lieu, ranged crockery overhead -// 'felicitous space' lost to the tribes ${ }^{26}$." By 1995, in other words, he had learned the diasporic lesson of the Irish masses and had reconstructed the Irish hearth as, perhaps, it had never existed for him at all. This is to say, in a sense that he expropriated Heaney's hearth and home, though the theft is accomplished at a properly literary and imaginative level. Yet the capacity to see home as a somehow sacramental (vrai lieu), just as Heaney sees homeland as "sacramental, instinct with signs", was, arguably, there all the time.

It was certainly there, though in an epistemologically modified form, in the concluding stanza of his poem "A Garage in West Cork", often regarded as the poor relation of the better-known "A Disused Shed in Co. Wexford". (Mahon himself has expressed misgivings about the final stanza and its striving for the same effect as the earlier poem. $)^{27}$ Of the Wexford poem Heaney once wrote: "This could be called visionary or symbolic" - although he tinkered endlessly with that phrase in subsequent printings of the essay in question and finally deleted it from the version in Finders Keepers ${ }^{28}$. The West Cork poem ends with a stanza - not always considered his best - that seems to exist precisely to sound that word in the most metaphysically-resonant fashion. It is about the decaying furnishings of empty homesteads, which, left to themselves, "will cast/A death-bead glow of picturesque abandon" - and this leads to a postmodernist generalisation:

The intact antiquities of the recent past,

Dropped from the retail catalogues, return

To the materials that gave rise to them

And shine with a late sacramental gleam $^{29}$. [Italics mine.]

If we look beyond Irish writing for the transcendental pedigree of gleam, we naturally meet it in Wordsworth's "Intimations of Immortality" in which the poet laments the failing imagination that inspired him in his vis-à-vis with nature in childhood and early manhood: "Whither is fled the visionary gleam? Where is it now the glory and the dream?" It is probably worth recording here a later - indeed, the very latest - incidence of the word in the Heaney calendar. This is to be met with in one of the interviews with Dennis O'Driscoll that forms the chapters of Heaney's virtual autobiography, Stepping Stones (2008). Here O'Dris-

26. The Hudson Letter, Gallery Press, 1996, p. 75-77.

27. William Scammell, interview with Derek Mahon, in Poetry Review [Special Irish Issue] Summer 1991, p. 6.

28. "Place and Displacement", in Andrews, op. cit., p. 131; compare Finders Keepers: Selected Prose 1971-2001, p. 120. In the preface to the former, Heaney explains that "Place and Displacement" (1984) "has for years enjoyed a separate life as a pamphlet, but now seems to belong in this more general reckoning".

29. Collected Poems, Oldcastle, Gallery Press, 1999, p. 131. 
coll asks him "whether he finds more "visionary gleam" in Kavanagh's Monaghan than in Yeats's "Byzantium", eliciting the reply: "No, as a reader, no".

The carrying power of the "Byzantium" stanzas is phenomenal. [...] There's something out of this world about Yeats's imagining, but the poetry itself still bears the brunt of the physical. [...] Still, you're right to imply that I'm much closer to the fundamentally Catholic mysticism of Kavanagh. My starlight came in over the half-door [...] not over the dome of a Byzantine palace. ${ }^{30}$

This leads on directly to the anomaly that, while Heaney's mind is actually postChristian, his poetical imagination lingers behind in (or goes forward to) a curiously metaphysical domain. The matter is encapsulated when O'Driscoll asks him directly after if the collection Seeing Things (1991) is informed by his "fardel" of inherited Catholic beliefs, "even if the very first poem is firm in its conviction that there is no after-life" - to which Heaney answers: "But it's also very firmly grounded in a sensation of "scope", of a human relation to the "shifting brilliancies" and the roaming "cloud-life". It's still susceptible to the numinous ${ }^{31}$. [My italics.]

Now, the "numinous" - meaning the presence of divinity - is something that we hear a great deal of in Irish poetry criticism, especially in relation to Derek Mahon. Terence Brown has told us that "Mahon [...] is absorbed by the way light falls on the visible world to invest it with numinous presence and an impression of inherent relationships ${ }^{32}$ ", while, on the basis of some strong hints from Mahon, he has authoritatively characterised his form of poetical inspiration as "secular mysticism"3" - a term similar to that other, "sceptical vision", which Brown affixed to Louis MacNeice in a no-less authoritative study ${ }^{34}$. Mahon has given an account of himself in which the numinous serves as the defining term:

I don't think I have a religious nature in that sense but I have a consciousness of things over and above, beside and below human life. I am deprived of belief in God, if deprivation it is, by my own rationalistic habits of mind, my own education, and yet [...] I make room for the numinous, for the unexplained ${ }^{35}$. [Italics mine.]

30. Dennis O’Driscoll, Stepping Stones: Interviews with Seamus Heaney, London, Faber \& Faber, 2009, p. 318. I have considerably abbreviated his deposition. We can take it that the reference is to "Sailing to Byzantium" and not the more arcane sequel "Byzantium".

31. Ibid., p. 319.

32. "Derek Mahon: The Poet and Painting", in Irish University Review, 24, 1, Spring/Summer 1994, p. 38-50, p. 42.

33. Terence Brown, "Introduction to Derek Mahon", Journalism: Selected Prose 1970-1995, Oldcastle, Gallery Press, 1996, p. 19.

34. See Terence Brown, Louis MacNeice: Sceptical Vision, Dublin, Gill \& Macmillan, 1975.

35. "Each Poem for me is a New Beginning", Cork Review, 2, 1981, p. 11. 
What is immediately striking about this is its resemblance to W. B. Yeats's account of his own attraction to myth and mysticism in the opening pages of his autobiography - and account to which Heaney clearly alludes when he introduces the word "fardels" into his question-and-answer with O'Driscoll. Yeats wrote famously: "I am very religious, and deprived by Huxley and Tyndall, whom I detested, of the simple-minded religion of my childhood, I had made a new religion, an almost infallible church, of poetic tradition, of a fardel of $\operatorname{stories}^{36} \ldots$..”

It could be felt, amidst these testimonies that there is a Catholic form of poetic mysticism, consisting in a residue of the old religion, and a Protestant form consisting in a reaction to the deprivation wrought by modern liberalism. It would take some time to unravel this in full, though I have no doubt that Yeats and Joyce are the signal instances, particularly in view of the lively interaction between them and, more particularly still in view of the transactions that surrounded the publication of $A$ Vision and Joyce's parody of certain parts of it in Finnegans Wake. Neither of them were naïve men, and both were probably agnostic in the commonly-accepted sense; but, while Yeats bullied himself into an attitude of spiritualistic credulity, Joyce took the coherence of medieval religion very much for granted and played his cosmological arpeggios up and down the scales of Thomistic theology without troubling himself in the least about the dogmatic truth of Catholic doctrines. In Stephen Hero young Joyce tells us that he feels "a genuine predisposition in favour of all but the premisses of scholasticism" - which is to say that he relishes the intellectual superstructure but dismisses the fideistic cornerstones. In Finnegans Wake he conjured up a neat apothegm on the question of the afterlife which we can safely assume to be his actual position (although Issy is the spokesperson): "Neither a soul to be saved nor a body to be kicked." Notwithstanding this, a resurrection myth plays the role of chief armature in the Wake though the specific mechanics of resurrection therein are remorseless scatological.

In common with T. S. Eliot and others of Anglican descent, Yeats was intensely earnest about the question of belief (one way or the other). In the only poem in which he engages with the nihilist proposition in full earnest, he expressed the darkest pessimism about the values that underpin our existence: "Civilisation is hooped together [...] by manifold illusion", he tells us in the poem "Meru": "but man's life is thought" and so he cannot help "ravening, raging and uprooting that he may come to the desolation of reality" [itals. mine] ${ }^{37}$. Given this dismal outlook - one broadly shared by Beckett - it is fortunate that he possessed a theory of the imagination that made it possible to plaster over the abyss which those lines so

36. W. B. Yeats, Autobiographies, London, Macmillan, 1955, p. 115-116.

37. Ibid., "Meru" [Philosophical Songs, XI], p. 333. It seems important that he says "that he may come", implying intentionality, rather than "until he comes" which might imply misadventure. 
powerfully evoke. That theory is most economically summed up in his famously ambiguous formulation about "the artifice of eternity ${ }^{38}$ ". Joyce, on the other hand, was wonderfully insouciant about the néant that probably underpins the edifice of art, culture and religion; and, so far from experiencing the paranoia about the "immense panorama of futility and anarchy which is contemporary history" that Eliot imputed to him in his famous essay on Ulysses ${ }^{39}$, he blithely professed in the persona of Stephen Dedalus that "the church is [...] founded irremovably because founded, like the world, macro- and microcosm, upon the $\operatorname{void}^{40 "}$. This did not make him a believing Catholic. It means, in fact, that he held a position not very remote from Seamus Heaney's as we further learn in Stepping Stones when O'Driscoll asks him if he wishes to emulate Yeats's systemmaking in $A$ Vision.

I suppose that - like many Catholics, lapsed or not - I am of the Stephen Dedalus frame of mind: if you desert this system, you're deserting the best there is, and there's no point in exchanging one great coherence for some other ad hoc arrangement ${ }^{41}$.

On the basis of such quotations - though the symmetry is obviously too simple - Heaney is of Joyce's mind and Mahon is of Yeats's.

The third poem that appears to be referenced in Mahon's anniversary tribute to Seamus Heaney is the title-poem of the collection Seeing Things (1991), the poem I have already spoken of as being dedicated to Mahon. Here the intertextual link is very slender but absolutely conclusive. Where Mahon seems to posit "[t]he world of simple fact" as the basis of a metaphysical intuition into the nature of being in its ever-recurrent form in the fourth stanza, he uses the Latin word "quidditas". Now this word is a virtual synonym for the "dry-eyed Latin word" Claritas which Heaney places in a front position of the second section of his titlepoem, "Seeing Things" - in structure a triptych. Both claritas and quidditas have a strictly Joycean pedigree. In A Portrait of the Artist as a Young Man (1916), Joyce famously explores the Thomistic triad integritas consonantia claritas in his quest for a definition of beauty. On closer examination the object of the quest is not so much beauty as an epistomological theory concerned with the act of perception or "apprehensiveness" (as he chooses to call it) involved in the recognition of any thing as "the thing that it is". In scholastic terms this is has to do with the

38. In "Sailing to Byzantium"; see W. B. Yeats, Collected Poems, Macmillan, 1950, p. 218.

39. T. S. Eliot, "Ulysses, Order and Myth", in The Dial, Nov. 1923, rep. in James Joyce: The Critical Heritage, ed.

Robert Deming, London, Routledge \& Kegan Paul, 1970, Vol. 1, p. 268-271; p. 270.

40. James Joyce, Ulysses, London, Bodley Head 1960, p. 267.

41. Stepping Stones, p. 319. 
cognition of what is called "signate matter", which Stephen later adverts to as "the signature of all things I am here to read" in the "Proteus" chapter of Ulysses.

It goes without saying that Joyce's theory is in no sense properly Thomistic but rather a specimen of modern psychology, sadly involving false analysis of what he calls the "phases" of perception - a temporal conception which has been comprehensively trashed by Gestalt psychology and related phenomenological approaches. St. Thomas was actually motivated by Trinitarian ideas: beauty had to correspond to the Holy Trinity in its number and quality. "Aesthetics" was not invented till Baumgarten in the eighteenth century yet, with wilful ingenuity, Stephen eludes the theological context and connects instead with the Aristotelian basis of Thomistic epistemology, identifying the third quality named by Aquinas not with claritas (or "radiance') but with "quidditas" (or "whatness"). Each of these terms actually appears in the text of $A$ Portrait. For reason to do with the development of $A$ Portrait between 1904 and 1916 through the intermediate draft called Stephen Hero, the latter actually supplies a more accurate account of what Joyce was actually thinking in 1904 when he polished his theory in about 1907. Uniquely, it equates claritas, quidditas and "whatness" with the term "epiphany" which is probably the best-known of Joyce's coinages - so well-known that even Homer Simpson bandies it with an Intuit shaman in Alaska (a feat attributable to twentieth-century college education in America).

Needless to say, epiphany is a much misused term today, widely taken to mean "a Eureka moment" or even a "road-to-Damascus" revelation. Joyce was more down-to-earth, meaning only that an epiphany revealed the actuality of things in their ordinary nature, stripped of the distortions of familiarity and cliché, hypocrisy and spiritual paralysis. Students of Joyce are apt to chastise those who import a more numinous sense into their reading of the word but there is good reason to believe that Joyce never forgot the etymological origins in Greek phainos, "light", and that he adorned his later works with light-tropism on account of it. When, for example, in Finnegans Wake, he composed the episode that revolves around the druid's phrase "panepiphanal world of Lord Joss" (614.14), he was thinking about the "chaosmos of Alle" in numinous terms while playing the part of the cosmologist with the comic brio of a true unbeliever. To be more exact, he was engaging in the central strategy of the symbolist writers: the creation of an artistic universe governed by the principle that Walter Pater calls "anti-metaphysical metaphysics" in Marius the Epicurian (1855). This is a conception with a definite legacy that embraces Oscar Wilde, W. B. Yeats and James Joyce - and I believe that it should be extended, mutatis mutandis, to Seamus Heaney and Derek Mahon.

How does Heaney use claritas in "Seeing Things?" In the first section he imagines a schoolboy outing to Inisboffin and a felt sense on his part of looking down as if from another boat, seeing "how riskily we fared" and "lov[ing] in 
vain our bare, bowed, numbered heads". This might fittingly be construed as an epiphany of the Troubles as they would come to bear on his generation of Ulster Catholics. It is also informed by the chief linguistic innovation of the whole collection: a tendency to frame synaesthetic neologisms at the point where physical experience passes over into imagination especially when physical sensation is elevated to the higher plain of psychic life conventionally occupied by the idea of spirit without ceasing to be a memory lodged in the human body. This is very much the point of the ambiguous title of the collection: seeing things is imagining them in the sense of seeing things that are not there as well as perceiving them as if the doors of perception were cleansed. Hughesian epithets such as "shiftiness and heft", "bouyancy and swim" carry sensations into the realm of abstraction and render possible the overview of self and others which the poem postulates as a natural, yet out-of-body, experience in the boy caught up on a Wordsworthian excursion.

In the second section, Heaney expatiates upon Joyce's term claritas in the somewhat improbable context of Gothic sculpture encountered in the course of a sweltering holiday in France, with some close attention to the symbolism of carvings on the tympanum of a cathedral door and the similar pattern of a mirage upon the road: "Claritas: The dry-eyed Latin word/is perfect for the carved stone of the water $[\ldots]$ the stone's alive with what's invisible [...] like a zig-zag hieroglyph for life itself". It is probably these lines that lie behind Mahon's "world of simple fact/gleam[ing] with water." In the third section, Heaney tells of an occasion when his father came close to dying in a farm accident: "Once upon a time my undrowned father...", ending "I saw him face to face [...] With his damp footprints out of the river,/And there was nothing between us there/That might not still be happily ever after ${ }^{42}$ ". The hermeneutic eye inevitably falls on that phrase "face to face" which is suitably Biblical to suggest an encounter with the actual and the transcendent Father at one and the same time. Essence and particular are united in a moment of trauma and release.

By claritas, then, Heaney means the mysterious presence of a natural thing in the very different material of an artistic medium: water in stone. As Joyce would say, "The soul of the commonest object seems to us radiant. The object achieves its epiphany". In Heaney's poem the idea of radiance in a moment of cognition conveyed by the "dry-eyed Latin word" claritas spreads out to embrace the whole poem: these are three epiphanies in the stream of experience which stand out because they had that quality of perception which marks them as real happenings in the domain of existential signification. Such happenings might occur, as Derek

42. Seeing Things (1991), p. 17; Opened Ground (1998), p. 339-341. In this context the "dry-eyed Latin word" claritas is called "perfect for the carved stone of the water" (ibid., p. 339). 
Mahon seems to suggest, in any place or period - hence "Quidditas: used fields/of Ulster and ancient Greece" in the fourth stanza of the anniversary poem.

I have spoken of the Copernican revolution by which Seamus Heaney translated himself from earth to air. Comparably, the sky above us has been a definite preoccupation of Mahon's since he translated portions of De Rerum Natura as "Lucretius on Clouds ${ }^{43}$ " and then briskly turned the revitalised lore of that ancient weatherman to moving effect in "The Cloud Ceiling", a poem addressed to his newborn daughter ("the indeterminate firmament is all yours [...] thirst pockets open for the infinite trip') - both poems appearing within a month of each other to the day in February-March 2002 ${ }^{44}$. Mahon's translation of Lucretius - a familiar text for university classicists - engages with the idea of a fusion of spirit and matter "in the blue sky [...] where flying bodies get tangled up together ${ }^{45}$ ". If his source seems pointedly archaic, it also involves a positive refusal to embrace the pragmatical pig of a world as defined by the TV weatherman and newsroom of our day. Aside from that, the final stanza of Mahon's tribute to Heaney is very like a profession of faith in the Heraclitan paradox that you can never step in the same stream twice, although there is really no other stream than the Herclitan flux. In Mahon's words:

and always the same river

The oracle and the universe, with no circumference, that infinite resource.

And then the clincher - an apothegm which, frankly, gives this reader some trouble: "If a thing happens once/it happens once for ever." I take this to mean, not that any event remains absolutely sui generis, isolated and random but that every event, however isolated shares in the unifying sameness of Being. Buddhism, existentialism, secular mysticism - which ever it may be, it offers what was seemingly absent from Mahon and always present in Heaney: the idea of earth and air, history and rhyme, as the hiding-place of hope.

Now, this is a somewhat Heideggerian idea especially as reflecting that philosopher's devotion to the Heraclitan dictum that "what was first was best" set out in his Introduction to Metaphysics $(1953)^{46}$. I do not mean to imply that Mahon is a student of that philosopher but he is certainly au fait with the thrust of Time and Being as befits the "make-believe" existentialist he once called himself in

\footnotetext{
43. "De Rerum Natura, 6, 451-523”, in The Times Literary Supplement (11 Feb. 2005).

44. "The Cloud Ceiling”, in The Times Literary Supplement (11 March 2005).

45. "De Rerum Natura, 6, 451-523", in The Times Literary Supplement (11 Feb. 2005).

46. See Irene Gilsenan Nordin, "A Way-Station Along the Way": Heaney and Heidegger and Wanderings and Home", in Nordic Irish Studies, ed. Michael Böss \& Nordin, 1, 1 (2002), p. 19-30.
} 
"Dawn at St. Patrick's ${ }^{47}$ ". There is much in his poetry that marks him out as no make-believe in this connection: every ligature in his bond with Samuel Beckett, for example, suggests an attitude of mind that refuses consolation but does not despair of hidden value at the very depths of le néant.

For much of his career as a poet, his attachment to the via negativa set him at odds with Seamus Heaney, whose version of spirituality was always positive to the point of sacerdotal confidence. In his contribution to Marie Heaney's anthology of Letters from Irish People on Sustenance for the Soul (1999), it was her husband who offered the fullest definition of the central matter at issue: "Spiritual sustenance", he wrote obligingly, means "whatever sustains the spirit, supports it from below, maintains its vitality and reinforces its sense of its own validity ${ }^{48}$ ". He continued: "What sustains is more returnable to, less surprising, less intense, more tried and chosen. It fact, it can sometimes seem that your sustenance ends up choosing you rather than the other way around." And then, reprising the liminal vision of Seeing Things, he identifies the moment of perception when spirit announces itself as a plausible idea: "The feeling of a gap closing and at the same time, equally and paradoxically, of a space opening. It seems at those moment that we are made for illumination ${ }^{49}$." In "A Country Kitchen", Derek Mahon appears to concur in that idea and to embrace the notion of epiphany in its transcendental sense. And with it, perhaps, he has swallowed the baptismal symbol which unites the three stanzas of "Seeing Things", imbibing the libation poured out by Heaney, complete with those visionary gleams - a form of higher absence which has been a subject of poetry since Wordsworth.

47. "Dawn at St. Patrick's", in Collected Poems, Oldcastle, Gallery Press, 1999, p. 105. St. Patrick's Hospital, Dublin, a mental asylum founded by Jonathan Swift, was for Mahon's purposes a drying-out hospital, as St John of God's is for Dublin Catholics. The relevant lines are: "I sit on my Protestant bed, a make-believe existentialist,/ And stare at the clouds of unknowing. We style,/ as best we may, our private destiny." [...] "Light and sane/I shall walk down to the train,/Into that world whose sanity we know,/Like Swift, to be a fiction and a show." (Ibid., p. 105-06.)

48. Sources (1999), p. 160.

49. Idem. 